\title{
Evaluation of geothermal potential of Mataruška Banja Spa (central Serbia) thermal mineral water
}

\author{
Natalija Ćirica, Kristina Milićević \\ University of Belgrade, Faculty of Mining and Geology, Department of Hydrogeology; Đušina 7, Serbia; \\ e-mail: natalija.cirica@rgf.rs
}

(C) 2016 Authors. This is an open access publication, which can be used, distributed and reproduced in any medium according to the Creative Commons CC-BY 4.0 License requiring that the original work has been properly cited.

Mataruška Banja Spa is located in central Serbia, around $180 \mathrm{~km}$ south of Belgrade on the northern slopes of the mountain massif Stolovi. The spa is characterized by moderate continental climate with an average annual rainfall of 740.3

$\mathrm{mm}$ and a mean annual temperature of $11.5^{\circ} \mathrm{C}$ and the low impact of the wind. Soon after the natural discovery of the existence of hot mineral water in Mataruška Banja Spa, after the floods of the Ibar River in the spring of 1897 , the water began to be used for treatment. Although its use as a heat source is also possible, this has not yet been achieved. Yield of over $30 \mathrm{l} / \mathrm{s}$ and temperature of $25-52^{\circ} \mathrm{C}$ from the existing wells are the most important facts when adopting positive assessment of the importance and cost-effectiveness of the application of this completely ecological and renewable resource. In the exploration area, there are 4 exploratory-abstraction wells, 2 dug wells and 3 probes, of which only MB-2/81, is functioning with water temperature of $48^{\circ} \mathrm{C}$. Despite the fact that the existence of these hot and healing water has been known for more than 120 years, the utilization for energy purposes has not yet been realized. Thermo mineral water of Mataruška Banja Spa has the highest content of sulphur hydrogen in Serbia - from $21 \mathrm{mg} / \mathrm{L}$ to $23 \mathrm{mg} / \mathrm{L}$ (Krunic 2012). From the aspect of hydrogeological characteristics, fissure aquifers within serpentinite and hydrothermally altered serpentinite are dominant, where thermo mineral water are accumulated. The circulation of thermo mineral waters is controlled by terrain tectonics, and specifically the existence of faults within the serpentinite and hydrothermally altered serpentinite. For the determination of the temperature in the geothermal reservoir, the calculation according to the formula for chemical geothermometers based on the content of individual components of the chemical composition of hydrogeothermal fluids has been used. Chemical equilibrium between rock minerals and their solution in water is most reliable method of determining the temperature in the reservoir. For temperature determination are attained silica (Fournier 1977) and $\mathrm{Na} / \mathrm{K}$ ratio (Fournier 1979) geothermometers and analysis of chemical composition of thermo mineral water. According to Cirica (2015) an average temperature value in reservoir is about $150^{\circ} \mathrm{C}$. Assumptions and estimates made in earlier studies (Milivojević 1990; Milenić 2008) confirm the results obtained by calculations. Insufficient knowledge of the reservoir is an important reason for interest in research of this reservoir. The assessment of the total geothermal energy has been performed on the basis of the available data on the yield of wells and water temperature from these facilities which is approximately $4283 \mathrm{~kW}$ (th). One of the uses of thermo mineral water is for balneological purpose. Therefore, the existing capacity of hydrothermal system will certainly be able to satisfy the upcoming needs of future generations. 
The aim of the research is to determine feasible options and actual available amount of energy from the existing wells, which is supported by the use of geothermometers regarding content of $\mathrm{SiO}_{2}$ and $\mathrm{Na}$ and $\mathrm{K}$ to define the maximum reservoir temperature. Accessibility geothermal energy in this area could bring many benefits, which would reduce the pressure on the use of fossil fuels and reduce greenhouse gas emissions.

\section{REFERENCES}

Ćirica N., 2015. Geotermalni potencijal termomineralnih voda Mataruške Banje. Faculty of Mining and Geology, Belgrade [final thesis].
Fournier R.O., 1979. A revised equation for the $\mathrm{Na} / \mathrm{K}$ geothermometer. Transactions - Geothermal Resources Council, 3, 221-224.

Fournier R.O. \& Potter R.W. II, 1982. A revised and expanded silica (quartz) geothermometer. Geothermal Resources Council Bulletin, 11, 10, 3-12.

Karingithi C.W., 2013. Chemical geothermometers for geothermal exploration. [in:] Short Course VII of Exploration for Geothermal Resources, Kenya.

Krunić O., 2012. Mineralne vode. Faculty of Mining and Geology, Belgrade.

Milivojević M., 2012. Geotermologija i geotermalna energija. Faculty of Mining and Geology, Belgrade.

Milenić D., 2008. Prethodna studija o opravdanosti supstucije fosilnog goriva SB Agens u Mataruškoj banji. Faculty of Mining and Geology, Belgrade.

Perić J. \& Milivojević M., 1990. Studija geotermalne potencijalnosti teritorije SR Srbije van teritorija SAP. Faculty of Mining and Geology, Belgrade. 